CIRJE-F-710

\title{
Insular Decision Making in the Board Room: Why Boards Retain and Hire Substandard CEOs
}

\author{
Meg Adachi-Sato \\ Royal Melbourne Institute of Technology University
}

January 2010; Revised in December 2013

CIRJE Discussion Papers can be downloaded without charge from:

http://www.cirje.e.u-tokyo.ac.jp/research/03research02dp.html

Discussion Papers are a series of manuscripts in their draft form. They are not intended for circulation or distribution except as indicated by the author. For that reason Discussion Papers may not be reproduced or distributed without the written consent of the author. 


\title{
Insular Decision Making in the Board Room: Why Boards Retain and Hire Substandard CEOs
}

\author{
Meg Adachi-Sato*
}

December 18, 2013

\begin{abstract}
This paper explores one reason why a corporate board often fails to replace a substandard CEO. I consider the situation in which the incumbent CEO and directors make decisions in the absence of the new CEO. I show that in this situation, which is common in practice, the board and the $\mathrm{CEO}$ end up maximizing the expected utilities of the negotiating parties that do not include the expected utility of the potential CEO. This sometimes results in the retention of an inefficient CEO. Moreover, I argue that this same logic provides a theoretical explanation for how a new CEO is chosen in relation to both the voluntary and enforced replacement of an existing CEO. Specifically, the equilibrium succession policy may depart from the optimum succession policy; that is, the optimum from the shareholders' perspective.
\end{abstract}

Keywords: CEO Succession Policy; Board Monitoring; Board Composition; CEO Firm-specific Knowledge.

JEL Codes: C78, G30, K22, L22, L29.

${ }^{*}$ Assistant Professor, Royal Melbourne Institute of Technology University, Melbourne, VIC 3000 Australia. E-mail: meg.sato@rmit.edu.au. I am extremely grateful to Richard A. Braun, Hideshi Itoh, and Kazuya Kamiya for their invaluable advice and constructive comments during the early stages of this research. I thank two anonymous referees, Ricardo Alonso, Bruce Chapman, Harrison Cheng, Leslie Hannah, Andrew Macrae, John Matsusaka, Chris Orme, Hiroshi Osano, and Pierre Picard for helpful comments and suggestions on this paper. I also acknowledge the comments of students in the ECON 604 Game Theory course offered at the University of Southern California along with participants in seminars at the University of Southern California, Tokyo University, Hitotsubashi University, and Australian National University. This paper was supported by the Global Center of Excellence (COE) Program, "The Research and Training Center for New Development in Mathematics." 


\section{Introduction}

A firm's board of directors is responsible for monitoring management on the behalf of shareholders. A CEO is assigned to perform the role of firm manager in a way that maximizes corporate profit for shareholders. However, the performance of the CEO does not always meet shareholders' expectations. In such a case, the role of the board is to replace the incumbent $\mathrm{CEO}$ with a new $\mathrm{CEO}$ who is more talented or better matched to the requirements of the firm and its shareholders. Despite this, corporate boards often find it difficult to replace an incumbent CEO.

This paper attempts to provide a theoretical rationale for actions by the board of directors that depart from shareholders' interests through the bargaining process between the incumbent board and the incumbent CEO. In the model, the incumbent board's initial objective aligns with that of shareholders, where the term 'initial' indicates the objective before bargaining. ${ }^{1}$ The starting point for this research is to investigate whether there is an advantage to be gained for the incumbent board members by retaining an incumbent substandard CEO, even though the expected corporate profit generated by appointing a new candidate is likely to be greater.

To attain this goal, I exploit a Nash bargaining game between two risk-neutral players; namely, the incumbent $\mathrm{CEO}$ and the board of directors. There is no information asymmetry between the players. The board of directors is treated as a single player, and hence, there is no free-rider problem. ${ }^{2}$ The incumbent CEO is perceived to have acquired firm-specific knowledge, which places him in a more advantageous position than potential CEOs in two respects $^{3}$ : it grants him bargaining power to negotiate his own wage and a rent. ${ }^{4}$ In this environment, the board of directors and the CEO bargain over three issues: the wage of the incumbent CEO, the succession policy, and the amount of money that the board is willing to pay to a specialist (or specialists) who monitors the incumbent CEO's conduct. I also assume

\footnotetext{
${ }^{1}$ Both the level of monitoring $p$ and the wage of the incumbent CEO $w$ are determined in the bargaining, as discussed in Section 3. Therefore, even though I do not explicitly model a stage prior to bargaining in this analysis, we can consider that both $p$ and $w$ are given prior to the bargaining stage. In this situation, the board's objective function completely aligns with the interests of shareholders.

${ }^{2}$ See Wilson (1968) for players with the same utility function treated as a single group.

${ }^{3}$ Hereafter, for simplicity, I refer to the CEO as being male.

${ }^{4}$ In this paper, the incumbent board does not bargain with potential CEOs, as in Aghion and Bolton (1987). Instead, the incumbent board bargains with the incumbent CEO because the incumbent CEO acquires firm-specific knowledge and has more bargaining power than any potential CEO. However, the same analysis is obtained when the model is constructed to allow the incumbent board to choose whether to negotiate with potential CEOs. See Appendix A5.
} 
that the larger the amount paid to the specialist, the more intense the monitoring; hence, I interpret this as meaning that the board and the incumbent CEO are determining the monitoring level. The term 'monitoring' in the analysis is used to refer to learning about the CEO's talent by reviewing his conduct, which is initially equally unknown to the board and the CEO. Based on the outcome of monitoring, the incumbent CEO may then be replaced with a potential CEO.

I show that when the two incumbent players bargain over these matters, the decision making is done in a way that maximizes only the joint expected payoff to the incumbent board and CEO, which does not internalize the utility of the potential newcomer to the current management group. Unlike issues that do not involve changes in the members of the management group, including decisions about the amount or choice of investment, the issuance of bonds or stock options, or policies oriented toward social reform, the decision to replace an incumbent CEO involves a change in the members of the management group. However, the concern of the incumbent decision makers is to maximize only 'their' own bargaining surplus. Thus, despite the fact there are three players who may be potentially affected by Nash bargaining, the two incumbent players who undertake the bargaining do not internalize the expected utility of the potential newcomer. As a result, the outcome of the process does not necessarily meet shareholders' expectations. ${ }^{5}$

Note that the potential newcomer to the management group differs according to succession policy. That is, if the new CEO is recruited externally, the potential newcomer is the new CEO; alternatively, if the new CEO is internally promoted from the existing board members, then the newcomer is the new board member invited onto the board to fill the resulting vacancy. Note that in the internal promotion case, however, if the board does not fill the vacancy, there is no newcomer. ${ }^{6}$ In what follows, I refer to the expected utility of the potential newcomer that should be internalized in the bargaining process as a leakage from the expected joint utility of the incumbent board and CEO. The analysis then shows that the incentive to minimize the leakage from the future surplus of the decision makers can account for inefficient CEO replacement.

\footnotetext{
${ }^{5}$ See Coase (1960).

${ }^{6}$ The board has two choices with internal promotion. The first is to keep the size of the board stable by appointing a new director after one of their number has been promoted to the position of CEO. The second is to reduce the size of the board by not hiring anyone after one of the directors has been promoted to the position of CEO. Logically speaking, the latter could happen. However, in practice, if the board continues not hiring a new director following an internal CEO replacement, the size of the board keeps contracting until there are no directors on the board. As this is unrealistic, I mainly consider the case in which the board fills the vacancy following internal promotion.
} 
The contribution of this paper is twofold. First, I identify a new cause for inefficient CEO retention. That is, because of the noninternalization of the potential newcomer's utility, the equilibrium monitoring level of the firm departs from the optimum monitoring level. This often results in CEO retention when CEO replacement is in fact optimal. More specifically, the monitoring level is determined at a level that reduces the probability of leakage. ${ }^{7}$

Second, I identify that the noninternalization of the potential newcomer's utility affects the choice regarding the appointment of a new CEO. As well as hiring a new CEO after the forced removal of an existing CEO, the board, along with the incumbent CEO, is responsible for choosing and appointing a new $\mathrm{CEO}$ when the incumbent $\mathrm{CEO}$ retires voluntarily. ${ }^{8}$ That is, the shareholders expect them to hire a new CEO either externally or internally based on the talent of the candidate. Very few studies have attempted to develop a theoretical model of how a new CEO is chosen. ${ }^{9}$ In this paper, I show that the succession policy is chosen not only by comparing the expected profits brought to the firm by the potential new CEO but also by comparing the amount of leakage. As leakage arises from the noninternalization of the potential newcomer's utility, the equilibrium succession policy may also depart from the optimum succession policy, the latter of which is the optimum from the shareholders' perspective.

The analysis in this paper provides the following empirical implications. To start with, Parrino (1997) finds that CEO replacement and outside succession are more frequently observed in homogeneous industries than in heterogeneous industries as it is easier for the board in homogeneous industries to identify a candidate with similar human capital required for the CEO's position. The theory developed in this paper is consistent with this finding. As firms in heterogeneous industries will have to recruit a CEO who has the appropriate human capital and experience, these firms incur significant search costs if they recruit externally. In addition, the new CEO's starting wage will be high. Thus, firms in heterogeneous industries tend to retain the incumbent CEO or replace him with insiders to keep the leakage small. Similarly, Berry et al. (2006) show that diversified firms require high-ability CEOs and that it is costly to find these CEOs in the managerial labor market. They also suggest that CEOs in diversified firms are more likely to be in this position through internal promotion than

\footnotetext{
${ }^{7}$ The concept of leakage is more comprehensively illustrated in Appendix A6, using a simple model based on a take-it-or-leave-it offer game.

${ }^{8}$ The board alone chooses the new CEO in the case of the forced retirement of the incumbent CEO. However, in the case of voluntary CEO replacement, the board and the incumbent CEO select the new CEO together. The succession policy considered in this paper can be applied to either case, as discussed in Subsection 3.1 and Appendix A4.

${ }^{9}$ The existing work by Raheja (2005) is discussed in Section 2.
} 
external recruitment. This paper provides another interpretation. If the talent of the insider and the outsider are not very different, the difference in additional profit brought to the firm is not so great whether an internal CEO or an external CEO is appointed. Even in this case, boards of diversified firms may prefer to recruit CEOs internally because internal promotion may not cause any leakage, while external recruiting always incurs leakage. Finally, there are many existing studies on CEO succession policy, for which the results are mixed. Some studies report that internal promotion is common, whereas others find external recruitment is more probable under certain conditions. ${ }^{10}$ The theory developed in this paper may then usefully explain why boards sometimes appoint an external candidate and other times promote an internal candidate. This may bridge the divergence in the existing empirical findings.

The insights provided in this paper also delve yet further into the relation between board composition and firm performance. For instance, Hermalin and Weisbach (1991) find no relation between firm performance and board composition, whereas Rosenstein and Wyatt (1990) and Byrd and Hickman (1992) identify a positive correlation between firm performance and board composition. In this analysis, as long as all of the directors on the board participate in the decision making, they share a common incentive: to minimize leakage from the incumbent group's utility. In other words, whether the directors are insiders or outsiders makes little difference in terms of the incentive to pursue their own utility maximization, which does not internalize the potential newcomer's utility.

In practice, the board may include different types of directors with dissimilar utilities. For instance, boards typically comprise a mix of independent directors, lawyers, friends/acquaintances of the CEO, relatives of the CEO, and academics, among others. In this paper, I assume that all directors have the same utility because the primary goal of this paper is to show that decisions made in the boardroom in the absence of a potential CEO can favor the incumbent CEO, even if none of the directors is associated with the incumbent CEO. To focus on this point, I consider that all directors have the same objective function uninfluenced by the CEO's friendship or fear of being ousted by him. Thus, the important message from the findings of this paper is that even if the board is constituted solely by independent directors, the leakage effect cannot be eliminated when decision making is done in the absence of a potential newcomer.

Indeed, most studies that examine the effect of independent or management-friendly boards on CEO compensation and replacement policy treat the board as a single entity.

\footnotetext{
${ }^{10}$ See Clutterbuck (1998), Ocasio (1999), and Agrawal et al. (2006).
} 
Alternatively, at most, they assume that the board has a single utility function in which the degree of board independence affects the costs incurred by the board in monitoring. See, for example, Hermalin and Weisbach (1998), Almazan and Suarez (2003), Hermalin (2005), Adams and Ferreira (2007), and Harris and Raviv (2010). This allows a clear-cut result and avoids unnecessary complexity. By contrast, some other studies are interested in considering the information transmission between insiders and outsiders or the allocation of corporate control and decision making between insiders and outsiders. See, for example, Raheja (2005) and Harris and Raviv (2008). These then examine the effect of information transmission and control allocation between insiders and outsiders on the value of the firm. Hence, these studies assume the heterogeneity of board members. As this paper is mainly concerned with CEO replacement policy, I follow the former procedure and view the board as a unique and homogeneous entity.

However, I should acknowledge that the paper focuses on only two of the many tasks undertaken by boards of directors; namely, the monitoring or replacement of the CEO. In reality, the role of the board is not limited to CEO monitoring and replacement. However, the insights in this paper remain useful for examining the process and outcomes of negotiations held between incumbent executives, and the relation between board composition and CEO replacement.

The remainder of the paper is organized as follows. Section 2 discusses the relevant literature. Section 3 constructs the theoretical model and discusses how the noninternalization of the potential newcomer to the board affects CEO tenure and decisions on CEO succession policy. Section 4 discusses an extension to the model developed earlier. Section 5 concludes.

\section{Literature Review}

There are several works in the literature that theoretically discuss the cause of board inertia regarding $\mathrm{CEO}$ replacement. However, no studies have argued that utility loss for the group - that is, the noninternalization of the potential newcomer's utility - is a possible cause of CEO retention.

This paper is closely related to Hermalin and Weisbach (1998). In Hermalin and Weisbach (1998), the incumbent board, which is considered as a single player that has collective preferences, and the CEO determine the wage of the incumbent CEO and a new director to be appointed to the board through Nash bargaining. This new board with the new director can be regarded as a different board from the incumbent board. After the Nash bargaining, 
this new board monitors the incumbent CEO. ${ }^{11}$ Thus, the incumbent CEO is willing to compromise his wage in exchange for appointing a new director likely to be loyal to him. Their main finding is that when the CEO is involved in appointing a new director, someone less independent from the CEO is appointed, and this weakens the board monitoring of the CEO, resulting in CEO retention. ${ }^{12}$ Their study measures the cost of monitoring with notation $\bar{k}$ : the board's lack of independence, where it changes from $\bar{k}_{0}$ (exogenously given) to $\bar{k}_{1}$ (endogenously determined) $\left(\bar{k}_{0}<\bar{k}_{1}\right)$ as the board members change. This $\bar{k}$ can be interpreted as a collective measure of comradeship or allegiance to the existing CEO, and they argue that the higher $\bar{k}$ is, or the stronger the comradeship or allegiance to the CEO, the less the board monitors the incumbent CEO. In short, the monitoring level and the measure of the board's lack of independence have a one-to-one correspondence, and we can consider that the incumbent board and the incumbent $\mathrm{CEO}$ are the players determining the monitoring level. Thus, the incumbent $\mathrm{CEO}$ remains in a firm for longer than he deserves according to his talent.

In sum, the reason for board reluctance to remove a substandard CEO in Hermalin and Weisbach (1998) is that the CEO selects the board members, and hence it is costly for the board whose members are less independent of the CEO to dismiss the incumbent CEO. Conversely, in this paper, I extend their model to focus on negotiations held by the current management group - specifically, the incumbent board and the incumbent CEOwhich would mostly take place in an insular boardroom. Both studies, of course, concern the board's inability to replace a substandard CEO, even when the board's objective function aligns with the interests of shareholders. However, the difference between this paper and Hermalin and Weisbach (1998) is that this paper focuses on the incentive of the current board members to retain the incumbent CEO in the absence of his influence on the board

\footnotetext{
${ }^{11}$ In Hermalin and Weisbach (1998), monitoring levels are defined through board composition, which is determined by the board and the incumbent CEO. Specifically, the incumbent board and CEO Nash bargain over some new board member, whose monitoring cost is determined by how independent the new director is from the incumbent CEO. In this paper, I interpret monitoring levels as the probability that the board and the CEO obtain information about the CEO's talent from the specialist whom they hire. All directors receive this information equally, and hence it is assumed that there is no information asymmetry among directors. Thus, when the incumbent board and CEO determine the amount that they pay the specialist, it can be considered that they are determining the monitoring level.

${ }^{12}$ Similar to Hermalin and Weisbach (1998), the CEO in this paper does not make an effort, and the monitoring is done to replace a poorly matched CEO with a new CEO, as the profit of the firm is dependent on the talent of the CEO. Adachi-Sato (2013) incorporates the effort of the incumbent CEO and studies how stock-based compensation can mitigate the moral hazard problem but can still affect the tenure of the incumbent CEO. See also Inderst and Mueller (2010) and Laux (2012) for the analysis of CEO tenure and incentives.
} 
members' utility. In other words, incumbent directors are not selected by the incumbent CEO or will not be fired by him, but they still have an incentive to undertake actions that would favor him. I then explain the current board's action with its incentive to avoid utility loss for the current management group. I show that the board, even though its members have no relationship with the incumbent $\mathrm{CEO}$, could still be an inefficient monitoring device. Hermalin and Weisbach (1998), on the other hand, consider the CEO's influence on the board's actions. That is, the incumbent CEO transforms the existing board members into new board members, and this new board finds it difficult to replace the incumbent CEO because they have been handpicked by the CEO. ${ }^{13}$ One very intuitive example that can be explained by the board behavior discussed in their model is the board of Disney when Michael Eisner was CEO. ${ }^{14}$ Another notable difference is that this study incorporates the process in which the board determines where to hire the next $\mathrm{CEO}$, an issue assumed to be exogenous in the model proposed by Hermalin and Weisbach (1998).

Raheja (2005) develops an interesting model in which she examines both board composition and new CEO appointment. In her model, inside directors and outside directors encounter asymmetric information about a project implemented by the CEO. Inside directors and the CEO have information about the type of project that the CEO has chosen, whereas outside directors do not have this same information unless shared by the inside directors. If inside directors do not share the information with the outside directors, they can enjoy a private benefit with the CEO. If the inside directors share the information with the outside directors, they enjoy the opportunity to become the next CEO if the outside directors succeed in verifying (monitoring) the bad project, or end up having nothing if the outside directors fail to verify (monitor) the bad project. In this environment, outside directors use succession policy to receive useful information from inside directors. Raheja's (2005) model implies that in order for boards to function as an effective monitoring device and to mitigate the problem of moral hazard, the board must comprise both inside and outside directors.

At first sight, the work by Raheja (2005) may appear similar to the present analysis, for it considers both the level of monitoring and CEO succession policy. In Raheja's (2005) paper, succession policy is the implementation mechanism that motivates insiders to reveal their

\footnotetext{
${ }^{13}$ In their model, CEO replacement can induce leakage. However, they do not discuss the effect on board decision making. Hence, I would like to extend their model by showing how the noninternalization of the potential CEO's welfare affects the decisions determined by the board.

${ }^{14}$ At the time, Disney claimed that 13 of its 16 board members were independent directors. However, it is well known that these so-called independent directors included the headmaster of the school and the president of the university that Eisner's child(ren) attended, Eisner's private attorney, and a paid consultant to Disney.
} 
superior information; that is, when outside directors could verify the bad project, the next $\mathrm{CEO}$ is voted in from one of the inside directors who had revealed the information. However, as the focus of her study is more on the mechanism for sharing information among directors, the CEO succession policy itself is not completely determined endogenously. Specifically, even though inside directors have a choice to reveal information or not, when it comes to appointing a successor, whether the CEO is hired externally or internally is given as a rule. In contrast, in my model, all directors are considered to have equal information, but the CEO's successor is determined endogenously in a game through maximizing the utilities of all incumbent members.

Several other studies also explain the inefficient replacement of the CEO by the board. For example, directors may fear ousting from the board when they do not succeed in replacing the CEO (Warther 1998). Similarly, CEOs may take deliberate actions to create specific human capital that makes it costly to replace them (Shleifer and Vishny 1989) or there may be factors affecting the information environment of the board (Adams and Ferreira 2007). This study provides a different perspective from these existing studies in that it shows how the outcome of negotiation becomes distorted when the incumbent CEO and the board discuss issues relating to member change in their group in the absence of a potential newcomer.

\section{Model}

\subsection{Basic Structure}

In this section, I show that CEO replacement induces a change of member in the management group, and this results in a certain utility loss to the incumbent members' group utility. This deprives them of the incentive to remove or monitor the incumbent CEO to avoid leakage unless the expected profit brought by a new CEO is large enough to compensate the amount of leakage. I also show that the type of leakage varies according to the succession policythat is, a choice arises between recruiting an internal candidate or recruiting an external candidate - and that incumbents prefer the succession policy with the smaller amount of leakage, all other things held equal.

For simplicity, I assume that the board and the incumbent CEO determine the succession policy together with the CEO's wage and the amount of money paid to the specialist reviewing the CEO's conduct. This setting may sound reasonable only for voluntary CEO retirement. However, I assert that the succession policy and the monitoring level need not be 
determined simultaneously in this model. Purely for the sake of simplicity, I determine these three decisions together in the model developed below. ${ }^{15}$ In other words, the board is not making a commitment to the succession policy determined prior to the CEO replacement. Hence, the logic in this paper is equally applicable to succession policy relating to enforced and voluntary CEO replacement.

\section{Players}

There are two players: the incumbent board and the incumbent CEO. I use the term 'board' to refer to $n$ directors acting as a single player. As all $n$ directors act as a single player, the board, there is no free-rider problem. The passive player is the new CEO, who is either promoted internally or recruited externally.

\section{Equilibrium Strategies}

The model comprises a cooperative game and a noncooperative game. In the cooperative game, the board and the incumbent CEO Nash bargain over the choice of a new CEO, the wage of the incumbent CEO $w$, and the amount $d(p)$ that they pay to the specialist for reviewing the CEO's conduct. ${ }^{16} 17$ In the noncooperative game, the board and CEO update their prior distribution of the incumbent CEO's talent with probability $p$. This $p$ is interpreted to be the probability of obtaining informative signal about the CEO's true talent, which is either $T$ talented or $S$ substandard. With probability $(1-p)$, the board and CEO obtain uninformative information about the CEO's talent. In the game defined below, the equilibrium strategy for the board is to replace the incumbent CEO when it believes him to be likely to be $S$, otherwise to retain him.

\section{Payoffs}

The incumbent CEO receives the endogenously determined wage $w$, and a noncontractible private benefit $b$ only when he is retained until the final stage. An example of $b$ is reputation, which will give him bargaining power in the future. The new CEO receives the starting wage. The new CEO's wage is $w_{O}$ if recruited externally, and $w_{N}$ if promoted internally from the incumbent board. The board's expected profit is assumed to be equal to the expected firm profit that is dependent on the distribution of the CEO's talent, $\pi_{k}$, where $k$ stands for the

\footnotetext{
${ }^{15}$ In Appendix A4, an identical result is obtained using the same logic when the board alone redetermines the succession policy after firing the incumbent CEO.

${ }^{16}$ What is determined in Nash bargaining is the equilibrium outcome of the board and CEO. The succession policy, the monitoring level $p$ and the wage $w$ are all determined in the Nash bargaining game, predicting the following noncooperative game.

${ }^{17}$ The specialist can be someone like an internal auditor, but the board may hire a more skilled specialist if it is willing to pay a high $p$.
} 
signal regarding the CEO's talent. ${ }^{18}$ Appendix A1 depicts in detail the process of deriving $\pi_{k}$ through the Bayesian update of the CEO's talent $\alpha_{k}$.

I denote $X$ as the random variable that represents the firm profit generated by the CEO. $X=X_{H}$ when the firm profit is high, and $X=X_{L}$ when the firm profit is low. Then, when the CEO's talent is given, the expected profit of the firm is denoted by $E(X \mid i)$ under the incumbent CEO or the new CEO recruited internally, where $i$ denotes the CEO's true talent; $T$ or $S .{ }^{19}$ Hence, when the CEO's talent is unknown, the expected firm profit is expressed as $\pi_{k}=\alpha_{k} E(X \mid T)+\left(1-\alpha_{k}\right) E(X \mid S)$ under the incumbent CEO or the new CEO recruited internally. $\pi_{k}$ is classified in the following four cases, $k=I, G, B$, or $N$ : the incumbent CEO's talent is not updated $(I)$, the incumbent CEO's talent is updated as more likely to be talented $(G)$, the incumbent CEO's talent is updated as more likely to be substandard $(B)$, or the new CEO is internally recruited following the dismissal of the incumbent CEO $(N)$.

The definition of $\alpha_{k}$ is given as follows. I assume that both the board and the incumbent CEO hold the prior probability distribution of the incumbent CEO's talent being $T$ with probability $\gamma^{T}>\frac{1}{2}$. Any other potential CEOs' prior distribution of their talent is assumed to be precisely $\frac{1}{2}$ for being $T .{ }^{20}$ Then, $\alpha_{k}$ is the probability of the incumbent or new internally recruited CEO being $T$ when $k=I, G, B$, or $N$. Indeed, $\alpha_{k}$ is determined through the Bayesian update. More specifically, if the incumbent CEO serves to the end of the game without his prior talent being updated by monitoring, $\alpha$ remains equal to the initial belief; $\alpha_{I}=\gamma^{T}$, and the firm profit is expected to be $\pi_{I}$. If the incumbent CEO is monitored and updated as more likely to be talented, $\alpha_{I}$ is updated to $\alpha_{G}=\mu_{G}^{T}$, where the precise definition of $\mu_{G}^{T}$ is in the Appendix A1, and the firm profit is expected to be $\pi_{G}$. If the incumbent CEO is monitored and updated as more likely to be substandard, $\alpha_{I}$ is updated to $\alpha_{B}=\mu_{B}^{S}$, and the firm profit is expected to be $\pi_{B}$, but this is not realized in the equilibrium because such a CEO would be replaced by a new CEO. If a new CEO is recruited internally following the dismissal of the incumbent CEO, $\alpha_{N}=\frac{1}{2}$, and the firm profit is expected to be $\pi_{N}$.

If a new CEO is recruited externally, the expected firm profit dependent on the distribution of the externally hired CEO's talent is expressed as $\pi_{O}=\frac{1}{2} E(Z \mid T)+\frac{1}{2} E(Z \mid S)$, as

\footnotetext{
${ }^{18} \mathrm{In}$ short, $\pi_{j}$ is the unconditional expected firm profit. From now on, I refer to it simply as an expected firm profit.

${ }^{19}$ Note that $E(X \mid i)=P_{H}^{i} X_{H}+P_{L}^{i} X_{L}$, where $P_{j}^{i}=\operatorname{Pr}\left\{X_{j} \mid a_{i}\right\}$, and $X_{j}$ is the profit of the firm for $j \in\{H, L\}$.

${ }^{20}$ In Hermalin and Weisbach (1998), the initial CEO's talent is updated before the negotiation in order to give the CEO some bargaining power. However, this process can be shortened by assuming the prior about his talent to be higher than that of any new potential CEO.
} 
the talent of any new CEO is assumed to be $\frac{1}{2} . Z_{j}, j \in\{H, L\}$ is the firm profit produced by the externally hired CEO, hence the expected firm profit conditional on $i$ is expressed as $E(Z \mid i) . E(Z \mid i)$ is defined similarly to $E(X \mid i)$.

As a result, the relations among firm expected profits are induced by the Bayesian update of $\alpha_{k}$, and they are $\pi_{G}>\pi_{I}>\pi_{O}>\pi_{B}$ and $\pi_{G}>\pi_{I}>\pi_{N}>\pi_{B}$. The difference between $\pi_{O}$ and $\pi_{N}$ comes from whether the new CEO is hired externally or internally from the incumbent board members. I do not specify the relation between $\pi_{O}$ and $\pi_{N}$, as there are both advantages and disadvantages for both types of potential CEO. ${ }^{21}$

\subsection{Timing}

There are four stages. The basic structure of the interaction between the board and the incumbent CEO follows from Hermalin and Weisbach (1998).

First stage: The firm has one incumbent $\mathrm{CEO}$ and the board of directors. All the incumbent members Nash bargain over the contract regarding the wage of the incumbent CEO, denoted as $w$, the amount $d(p)$ that they pay to the specialist who monitors the incumbent CEO, and the succession policy about whether to hire a new CEO externally or internally. Note that $p$ is interpreted as the intensity of monitoring by the specialist, and this equals the probability that the board obtains informative signal about the incumbent CEO's talent. At this stage, the initial belief of the board and the incumbent CEO regarding the incumbent CEO's talent being $T$ is $\gamma^{T}$, whereas their initial belief about any other potential CEO's talent being $T$ is $\frac{1}{2}$.

Second stage: The specialist monitors the CEO's conduct and provides information, $y_{k}$, $k=I, G, B$ to the board of directors. Based on this information, the board updates the subjective probability distribution of the incumbent CEO's talent. Hence, this information $y_{k}$ is identified with the signal $k \in\{I, G, B\}$ that is defined in Subsection 3.1. The incumbent CEO also equally learns the signal information. With probability $p$, the board receives information $\left\{y_{G}, y_{B}\right\}$. With probability $(1-p)$, the board receives uninformative information $y_{I}$, and the subjective probability distribution of the incumbent CEO's talent remains

\footnotetext{
${ }^{21}$ For example, outside CEO candidates may be management experts in the same industry and may be talented. However, they may not fit the culture of the firm. On the other hand, insider CEO candidates may be very knowledgeable about their firm but, at the same time, may not be able to make the necessary changes in management. Bower (2007) argues that an insider with an outsider's perspective, which he refers to as an "inside outsider," would be the best successor. As it is beyond the scope of this paper to argue about inside outsiders, I assume the priors about the talent of both candidates to be the same, even though the outcome may be different.
} 
unchanged.

Third stage: The board retains or replaces the incumbent CEO based on the information. Given $\pi_{G}>\pi_{I}>\pi_{O}>\pi_{B}$ and $\pi_{G}>\pi_{I}>\pi_{N}>\pi_{B}$, the board retains the incumbent CEO when it receives either $y_{G}$ or $y_{I}$; it fires the incumbent CEO when it receives $y_{B}$, and it hires a new CEO externally or internally based on the decision made in the first stage. I assume that none of the directors leaves with the incumbent CEO after the incumbent CEO is found to be mismatched with, or has caused some damage to, firm value. This can be theoretically justified in that as each director's objective function is congruent with the shareholders' interest, the main result is unaffected if some or none of the directors leave the board. ${ }^{22}$ Moreover, in practice, the case in which all or a majority of directors are removed following CEO replacement is rare. ${ }^{23}$ See Appendix B for anecdotal evidence of the CEO being fired while the remaining board members are retained, even though the failure in management has caused extensive damage to the firm.

Fourth stage: Production is made and all the players receive their pay.

\subsection{The Players' Objectives}

The number of directors $n$ on the board, the private benefit $b$ that the CEO receives at the end of the game, and the wages to the newly hired CEO, $w_{O}$ if recruited externally, and $w_{N}$ if recruited internally, are exogenously given. ${ }^{24}$ In addition, I define $q=\operatorname{Pr}\left(y_{G} \mid e\right)$, and $1-q=\operatorname{Pr}\left(y_{B} \mid e\right)$ where $e$ denotes the event of the board receiving information, $y_{G}$ or $y_{B} \cdot{ }^{25}$

The incumbent CEO's expected utility is expressed as:

$$
[p q+(1-p)] b+w
$$

\footnotetext{
${ }^{22}$ To be more precise, suppose the number of board members who will be fired with the incumbent CEO is fixed. For example, suppose it is fixed at $20 \%$. Then, it would only increase leakage by $20 \%$. This does not affect the primary result of this paper.

${ }^{23}$ Board members, of course, do change over time. However, a change in board membership triggered directly by CEO replacement should be considered to take place within a few months.

${ }^{24}$ From the perspective of game theory, the wage $w_{N}$ that will be paid to the internally promoted CEO could be endogenously determined. If the model were built in this way, the incumbent directors would increase the amount of wage $w_{N}$ as much as possible. This is because $\frac{n-1}{n} \pi_{N}+b+\frac{1}{n} w_{N}$ can be derived from the expression (3) presented later in this subsection. However, the shareholders will not allow such high wage to be determined by the inside directors, and hence it would be unrealistic.

${ }^{25} q$ depends on $\gamma^{T}$. Because $\gamma^{T}$ is exogenously given, $q$ is also exogenous. Suppose $\gamma^{T}=\frac{2}{3}$ and $\gamma^{S}=\frac{1}{3}$. Suppose that when monitored, the CEO shows good performance with probability $\frac{3}{4}$, when his true type is $T$ and shows good performance with probability $\frac{1}{4}$ if his true type is $S$. In this setting, the probability of observing good performance, that is $y_{G}$, is $\frac{2}{3} \cdot \frac{3}{4}+\frac{1}{3} \cdot \frac{1}{4}=\frac{7}{12}=q$.
} 
for he surely receives the wage $w$ determined in the negotiation, but the private benefit $b$ is only given when he is retained to the end of the game. The CEO is retained when the board receives $y_{G}$, which occurs with probability $p q$, or $y_{I}$, which occurs with probability $(1-p)$. In other words, if the incumbent CEO is dismissed prior to the last stage, he will not obtain $b$.

The expected utility of the board, which is the total of the $n$ incumbent directors, differs by where they choose the new CEO from.

If the new CEO is to be recruited externally, it is expressed as:

$$
n p q \frac{\pi_{G}}{n}+n p(1-q) \frac{\pi_{O}-w_{O}}{n}+n(1-p) \frac{\pi_{I}}{n}-d(p)-w .
$$

The first and the second terms in (2) are the expected utilities of the board when it receives information about the incumbent CEO. With probability $p q$, the board receives $y_{G}$, and each director on the board will receive $\frac{\pi_{G}}{n}$. With probability $p(1-q)$, the board receives $y_{B}$, and hence the board replaces the incumbent CEO. Then, each director on the board will receive $\frac{\pi_{O}-w_{O}}{n}$. The wage $w_{O}$ is paid to the new CEO, who will be hired externally. The new CEO does not have any bargaining power, and hence the amount of this wage is assumed to be determined in the market. The new CEO, if hired with probability $p(1-q)$, will also obtain the private benefit $b$, but this is not internalized in either the board utility or the incumbent CEO's utility. ${ }^{26}$ The third term in (2) is the utility of the board when the incumbent CEO is retained as a result of the board receiving signal $y_{I}$. The fourth term $d(p)$, where $p \in[0,1)$, is the cost of monitoring, which is a strictly increasing, strictly convex, twice-continuously differentiable function. I assume $d^{\prime}(0)=0$, and $d^{\prime}(p) \rightarrow \infty$ as $p \rightarrow 1$, which derive interior solutions. The fifth term, $w$, is the wage paid to the incumbent CEO.

Alternatively, the expected utility of the board is expressed as the following if the new CEO is recruited internally from the incumbent board members:

$$
n p q \frac{\pi_{G}}{n}+p(1-q)\left[(n-1) \frac{\pi_{N}-w_{N}}{n}+b+w_{N}\right]+n(1-p) \frac{\pi_{I}}{n}-d(p)-w
$$

I assume that each internal director has an equal opportunity of being promoted to be the new CEO. This is reflected in the second term of (3). ${ }^{27}$ That is, when the board obtains $y_{B}$ with probability $p(1-q)$, the incumbent CEO is fired. Then, one of the internal directors is

\footnotetext{
${ }^{26}$ The main result in this paper will not be affected if the amount of $b$ is different for a CEO who was monitored and retained versus one who was retained without monitoring.

${ }^{27}$ The second term in $(3)$ can be re-written as $p(1-q) \cdot n\left[\frac{(n-1)}{n} \frac{\left(\pi_{N}-w_{N}\right)}{n}+\frac{1}{n}\left(b+w_{N}\right)\right]$.
} 
promoted to be the new CEO, while the remaining directors stay on the board. That is, the new CEO will receive $w_{N}$, while the remaining $n-1$ directors each receive $\frac{\pi_{N}-w_{N}}{n}$. As the newly promoted CEO is unmonitored, he is expected to receive both the wage $w_{N}$ and the private benefit $b .^{28}$ To fill the vacancy on the board caused by the internal promotion, a new director will be appointed. The payment to the new director is $\frac{\pi_{N}-w_{N}}{n} \cdot{ }^{29}$ This new director's expected utility is not internalized in either the expected utility of the current board or the expected utility of the incumbent CEO. Note that the expected payment of $w_{N}+b$ to the new CEO is internalized, for he is the original incumbent member. The other terms are as $(2)$.

\subsection{Analysis of Board Decision Making: Succession Policy and CEO Retention}

In this subsection, I show that both incumbent players in this model have an incentive to maximize their joint expected utility when making decisions. This is because the players' utilities are transferable and because they Nash bargain. ${ }^{30}$ Thus, maximizing the joint expected utility expands the feasible set. However, inefficiencies arise when they are not internalizing the expected utilities of potential newcomers who might join the board in the future.

In what follows, I discuss how monitoring levels and succession policies are determined when the incumbent board members are not internalizing the potential newcomer's utility.

Nash product is either:

$$
\begin{aligned}
V_{O} \equiv & \left\{p\left[q \pi_{G}+(1-q)\left(\pi_{O}-w_{O}\right)\right]+(1-p) \pi_{I}-d(p)-w-\theta_{B}\right\} \\
& \times\left\{[p q+(1-p)] b+w-\theta_{C}\right\}
\end{aligned}
$$

\footnotetext{
${ }^{28}$ I assume that the new CEO is unmonitored only to simplify the analysis. The main result would be the same even if he were monitored. That is, the purpose of this paper is to show how negotiations between the CEO and the board distort the CEO replacement if they are done in the absence of the potential new CEO.

${ }^{29}$ Note that there are two possible cases for newcomers. When the board recruits the CEO externally, the newcomer is the new CEO. When the board promotes one of the incumbent directors to the board, the newcomer is then the new director who is hired to refill the board. In the long term, the board size may decrease, but in the short term, the board needs to retain a certain number of directors to maintain its operations. Moreover, refilling the board has an aspect of providing incentives to workers to work hard in order to be internally promoted to be a director in the future.

${ }^{30}$ The wage $w$ is subtracted from the incumbent board's expected utility and added to the incumbent CEO's expected utility as $w$. See Appendix A2 for details.
} 
or:

$$
\begin{aligned}
V_{I} \equiv & \left\{p q \pi_{G}+p(1-q)\left[(n-1) \frac{\pi_{N}-w_{N}}{n}+b+w_{N}\right]+(1-p) \pi_{I}-d(p)-w-\theta_{B}\right\}(5) \\
& \times\left\{[p q+(1-p)] b+w-\theta_{C}\right\} .
\end{aligned}
$$

The difference between (4) and (5) derives from where the new CEO will be hired: Nash product (4) is when the new CEO is going to be externally hired, while (5) is when the new CEO is going to be internally promoted. The threat points are expressed as $\left(\theta_{B}, \theta_{C}\right)$ for (4) and (5). That is, if the negotiation breaks down, the board will receive $\theta_{B}$, and the incumbent $\mathrm{CEO}$ will receive $\theta_{c}$.

Under a given succession policy, the players determine the optimum monitoring level $p^{*}$ that will attain the highest Nash bargaining frontier. Note that the Nash bargaining frontier is linear at 45 degrees. As shown in Appendix A2 and Figure 1, the bargaining frontier can be expressed as the sum of the board's expected utility and the incumbent CEO's expected utility. Hence, when comparing the two succession policies, the board decides to adopt the succession policy with the highest bargaining frontier, where the highest attainable level is different between the two succession policies. ${ }^{31}$ Thus, the succession policy that achieves a higher bargaining frontier will be chosen. ${ }^{32}$ However, one policy does not always have a higher frontier than the other policy; for example, external recruiting is not always better than internal recruiting, and vice versa. Whether one policy is more desirable than the other depends on the difference between the expected profits brought to the firm by the new CEO and the amount of leakage that occurs.

I first show how the optimal succession policy is determined given the monitoring level. The joint expected utility of the incumbent members when the new CEO is externally hired is expressed as:

$$
p q \pi_{G}+p(1-q)\left(\pi_{O}-w_{O}\right)+(1-p) \pi_{I}-d(p)+[p q+(1-p)] b-\theta_{B}-\theta_{C}
$$

which is the addition of (1) and (2). The joint expected utility of the incumbent members when one of the internal directors is promoted to be the new CEO is expressed as:

$$
p q \pi_{G}+p(1-q)\left[(n-1) \frac{\pi_{N}-w_{N}}{n}+b+w_{N}\right]+(1-p) \pi_{I}-d(p)+[p q+(1-p)] b-\theta_{B}-\theta_{C}
$$

\footnotetext{
${ }^{31}$ Free disposal is assumed. As the frontier is linear, the feasible set of Nash bargaining is convex.

${ }^{32}$ As one or the other feasible set always encompasses the other, the feasible set with the higher frontier always makes the players better off.
} 
which is the addition of (1) and (3).

In comparing the above two expressions, the sufficient condition to hire a CEO externally is expressed as:

$$
\pi_{O}+b-\left(w_{O}+b\right)>\pi_{N}+b-\frac{1}{n}\left(\pi_{N}-w_{N}\right),
$$

and the sufficient condition to promote an internal director to CEO is expressed as:

$$
\pi_{O}+b-\left(w_{O}+b\right)<\pi_{N}+b-\frac{1}{n}\left(\pi_{N}-w_{N}\right) .
$$

The possible gross expected payoff to the incumbent players is $\pi_{O}+b$ if the new CEO is recruited externally, and it is $\pi_{N}+b$ if the new CEO is recruited internally from the incumbent board. The leakage to the newcomer is expressed as $w_{O}+b$ for the former, while it is $\frac{1}{n}\left(\pi_{N}-w_{N}\right)$ for the latter. $w_{O}+b$ represents the expected pay to the externally hired CEO, while $\frac{1}{n}\left(\pi_{N}-w_{N}\right)$ represents the expected pay to the new director who is appointed to the board to maintain the board size at $n$. Recall that the internally promoted new CEO is the original incumbent board member, so any expected payment that he will receive is not considered as a leakage from the whole group.

Given the above argument, the incumbents' decision to promote an internal director or to recruit externally is determined by comparing the amount of difference between the leakages and the amount of difference between the expected profits brought to the firm by the potential CEOs. This trade-off leads to the following proposition.

Proposition 1 The incumbent executive members' decision to appoint an internal or external CEO is based on how small they can keep their utility loss. In other words, incumbent executives do not simply compare the expected profits that internal and external CEOs bring to the firm; rather, they compare the expected profit less the leakage from the expected group utility of the incumbent executives. Thus, the incumbent executives decide to recruit externally when (8) holds, and they decide to promote one of the internal directors as a successor CEO when (9) holds.

The logic behind Proposition 1 is as follows. Even if the expected profit brought by the potential external CEO is larger than that brought by the potential internal CEO, $\pi_{O}>\pi_{N}$, the board appoints the potential internal CEO if the sum of starting wage of the external CEO $w_{O}$ and the control benefit $b$ is large enough to exceed the additional expected profit, $\pi_{O}-\pi_{N}$. Similarly, even if the expected profit brought by the potential internal CEO is larger than that brought by the potential external CEO, $\pi_{N}>\pi_{O}$, the board appoints the 
potential external $\mathrm{CEO}$ if the starting wage of the external $\mathrm{CEO} w_{O}$ and/or the control benefit $b$ are sufficiently small.

The theoretical implication of Proposition 1 is as follows. First, in this model, the starting wage of an externally hired new CEO is given exogenously as $w_{O}$, but even if I were to interpret this as a total cost in appointing a new external $\mathrm{CEO}$, it would not affect the main result of the paper. Hence, I can interpret $w_{O}$ as the starting wage plus the search cost. Second, while external promotion always causes leakage from the total expected utility of the incumbent executives, an internal promotion can cause no leakage if the board is not refilled for a short time. In this case, if the talent of the new CEOs are expected to be about the same as to bring the same amount of expected firm profit, $\pi_{N}=\pi_{O}$, the incumbent executives will choose to promote internally one of their directors to the post of CEO because doing so would incur no leakage. These arguments lead to the following corollary.

Corollary 1 Suppose that the firm is willing to reduce the board size in the short run. Then, the current executives are willing to appoint an internal candidate to the post of CEO when the internal CEO candidates and the external $\mathrm{CEO}$ candidates are expected to have similar talent, or if it incurs too much search cost to find talented external candidates.

The empirical implication of Proposition 1 and Corollary 1 is as follows. Berry et al. (2006) argue that diversified firms require talented CEOs, and they provide empirical evidence that diversified firms are then less likely to replace their CEOs than focused firms and that diversified firms are more likely to promote insiders internally to the post of CEO. As diversified firms require talented CEOs, it could be said that in diversified firms, the board incurs significant search costs to find a talented external potential CEO. With a small search cost, it could only find an external potential CEO of average talent. Then, because $\pi_{N}-\pi_{O}$ is likely to be small while $w_{O}$ is likely to be large, the board finds it in its own interest to promote an internal candidate to the post of CEO rather than to appoint an average external potential CEO in diversified firms. Parrino (1997) gives empirical evidence that CEO replacement and outside CEO succession are more frequently observed in homogeneous industries than in heterogeneous industries, because firms in heterogeneous industries incur significant search costs if they recruit CEOs externally. Repeating the above argument, Proposition 1 and Corollary 1 are consistent with this empirical evidence.

Corollary 1 can also explain the recent CEO replacement at Groupon, Inc. in 2013. In Groupon, when the CEO was fired in February, none of the directors left with him. The board searched for a new CEO for five months, but in August, they announced that one of 
their internal board members, in fact the chairman, would be the successor CEO. The size of the board has contracted. The case of Groupon does not involve the incumbent CEO in the appointment process of a new CEO, but as proved in Appendix A4, the theory developed in this paper is applicable to such cases as well. Therefore, the Groupon case shows that the internal board members found the search for an external CEO too costly and too difficult, so they promoted one of their incumbent board members to the position of CEO.

Next, I show how the monitoring levels are determined.

Proposition 2 For a given succession policy, the monitoring level is uniquely determined.

1. If the board determines to recruit externally, it is:

$$
d^{\prime}(p)=q \pi_{G}+(1-q) \pi_{O}-\pi_{I}-(1-q)\left(w_{O}+b\right) .
$$

2. If the board determines to promote one of the internal incumbent directors, it is:

$$
d^{\prime}(p)=q \pi_{G}+(1-q) \pi_{N}-\pi_{I}-(1-q) \frac{1}{n}\left(\pi_{N}-w_{N}\right) .
$$

Proposition 2 suggests that because of the noninternalization of the potential newcomer's utility, the equilibrium monitoring levels are attenuated by the amount of leakage. This often results in CEO retention when CEO replacement is in fact optimal for the firm. Monitoring levels are the proxies for CEO retention in this model. This implies that CEO retention is determined at a level that reduces the probability of leakage.

The monitoring levels are determined at the level that achieves the highest possible Nash bargaining frontier, given the succession policy. The leakage that the incumbent board incurs by replacing the CEO is reflected in the last term of both (10) and (11). That is, with probability $(1-q)$, the incumbent CEO is fired, a newcomer is hired, and leakage from the bargaining surplus occurs as $w_{O}+b$ or $\frac{\pi_{N}-w_{N}}{n}$. If the board brings an external CEO into the firm, the new CEO is the newcomer, and the wage $w_{O}$ and the benefit $b$ are the leakage. When one of the internal directors is promoted to CEO, the board hires a new director to maintain the number of directors at $n$. Thus the payment of $\frac{\pi_{N}-w_{N}}{n}$ is given to this new director, and this is considered a leakage, at least from the perspective of the incumbent board members. In short, monitoring levels are attenuated for both (10) and (11) because the incumbent executives who determine the monitoring level wish to minimize the utility loss from their own group utility. ${ }^{33}$

\footnotetext{
${ }^{33}$ Note that this is different from the CEO and the board colluding.
} 
The implications of Proposition 2 is as follows. First, the larger the leakage, the lower the monitoring level, $p$. This reduces the probability of the board obtaining precise information about the CEO's talent. As the monitoring level is interpreted as the probability of obtaining precise information, the board obtains $k=G$ or $B$ with probability $p$, but with probability $(1-p)$, the board obtains $k=I$. The firm's expected profit is determined by the CEO's updated talent $\alpha$ and the signals of the CEO's talent $k$, and described as $\pi_{G}>\pi_{I}>\pi_{O}>\pi_{B}$ and $\pi_{G}>\pi_{I}>\pi_{N}>\pi_{B}$. In short, less monitoring reduces the probability of the firm having $\pi_{G}$.

Next, internal promotion can provide an incentive to incumbent insiders to monitor the incumbent CEO. This is similar to Raheja (2005) in the sense that succession policy is used to remove a substandard CEO but I apply different logic. That is, in this paper, the higher the wage $w_{N}$ of the new internally promoted $\mathrm{CEO}$, the stronger the board incentive to monitor the incumbent CEO (see (11)). In short, if the new CEO's wage is to some extent large, it causes virtuous competition among the inside directors.

Lastly, the expected utility of the board under the external-recruiting policy is expressed as (2). This can be considered as a board that is composed solely of outside directors. ${ }^{34}$ On the other hand, the expected utility of the board under the internal-promotion policy is expressed as (3), and this can be interpreted as the expected utility of a board composed solely of inside directors. ${ }^{35}$ Therefore, regardless of board composition, the board may find it in its own interest to retain the incumbent CEO.

\section{Extension: Internalization of the Newcomer's Wel- fare}

\subsection{Social Surplus Maximization}

Below I show that when the incumbent board members do internalize the newcomer's utility, the monitoring level is higher than the equilibrium monitoring levels determined by the

\footnotetext{
${ }^{34}$ Note that when the board decides to recruit the new CEO from outside the board, none of the incumbent directors becomes a CEO candidate. One way to interpret this type of board is to consider it as a board composed solely of outside directors who have their primary job elsewhere, such as with an academic, and hence have less incentive to become the successor CEO of the firm in which they are serving as an outside director.

${ }^{35}$ When the board decides to recruit the new CEO from within, all of the incumbent directors become potential CEOs. Thus, the board with the internal-promotion policy can be considered to have the same expected utility as the board composed solely of inside directors.
} 
incumbent board and CEO, and the succession policy equals the optimum succession policy for shareholders.

The optimum succession policy is to hire a new CEO expected to bring a higher net expected profit:

$$
\max \left\{\pi_{O}-w_{O}, \pi_{N}-w_{N}\right\} .
$$

This is the optimum for all three players: the incumbent CEO, the board, and the potential newcomers. For simplicity, I assume $w_{O}=w_{N}$. Then, (12) is expressed as:

$$
\max \left\{\pi_{O}, \pi_{N}\right\} .
$$

This equals the optimum from the shareholders' perspective as well.

Because the players' utilities are transferable, and they all Nash bargain, the optimum monitoring level is determined so as to maximize the joint expected utility of all players, including the incumbent members and the newcomers. A newcomer is a new CEO under the external-recruiting policy and a new director under the internal-promotion policy, who may be appointed to the board after the CEO is replaced. The joint expected utility of such a case is expressed as:

$$
p q \pi_{G}+p(1-q) \max \left\{\pi_{O}, \pi_{N}\right\}+(1-p) \pi_{I}-d(p)+b .
$$

See Appendix A3 for the proof. Taking the first-order condition with respect to $p$ induces the optimum level of monitoring:

$$
d^{\prime}(p)=q \pi_{G}+(1-q) \max \left\{\pi_{O}, \pi_{N}\right\}-\pi_{I} .
$$

Equation (15) shows that when the incumbent board members internalize the expected utility of future newcomers to the board, the board monitoring level is not attenuated by leakage, which is either $w_{O}+b$ or $\frac{\pi_{N}-w_{N}}{n}$.

\subsection{Reemployment of the Retired CEO}

Theoretically, the social surplus maximization described in Section 4.1 is attained if there is no newcomer to the incumbent management group. If there is no newcomer, the monitoring level becomes more intense, and the probability of removing an inefficient CEO increases. One way to achieve this is to reemploy the retired CEO in a director's position under an internal-promotion system. Under an internal-promotion system, if the incumbent CEO 
departs, one of the directors becomes the CEO. Instead of hiring a new director to maintain the board size at $n$, if a retired CEO is hired/remains as a director, there is no leakage. The idea is to reemploy the CEO who was participating in the negotiation instead of hiring a new director or promoting a successful worker to the position of director. This leads to the following proposition.

Proposition 3 The monitoring level with no newcomer to the corporate board is expressed as:

$$
d^{\prime}(p)=\left[q \pi_{G}-\pi_{I}+(1-q) \pi_{N}\right]
$$

Note that (16) equals the optimum level of monitoring (15), when $\pi_{O} \simeq \pi_{N}$ holds. Hence, the monitoring level is always larger than (11). Even though the incumbent CEO might not have been a good match as a manager leading the firm, given his knowledge and experience and the firm-specific skills, he may still remain on the board as one of the directors who participates in principle decision making.

However, reemployment is only practical for the case of voluntary CEO retirement. Moreover, even in the case of voluntary CEO replacement, if the incumbent CEO was a powerful CEO who enjoyed his perks to their maximum level, he would still be doing that if he retired as CEO and served as a chairman or a director on the board. This would not serve shareholders' interests. Furthermore, even if reemployment of the retired CEO were possible in practice, reemploying the retired CEO may happen once, but this is not realistic for all $n$ members on the board who have been promoted to the new CEO's post. Therefore, in the real world, what has been discussed in Section 3 is more applicable.

\section{Conclusion}

This paper provides an explanation for inefficient CEO retention and CEO appointments. The succession policy, the incumbent CEO's wage, and the monitoring level are determined by all of the incumbent directors and the incumbent CEO. When they jointly determine these matters, they do not internalize the utility of the potential newcomer. Thus, the incumbents are maximizing their joint expected utility, but this process involves utility leakage from the whole group. I show that the equilibrium monitoring level departs from the optimum monitoring level of the firm, too often resulting in retention of a substandard CEO. I also show that the equilibrium succession policy may depart from the optimum succession policy, the latter of which is the optimum from the shareholders' perspective. 
In this model, the incumbent board and CEO do not negotiate with the potential CEOs, if only to simplify the exposition. This means that, irrespective of whether the model allows the board and CEO to have a choice of negotiating or not negotiating with the potential CEOs, they may choose not to involve a potential new CEO if they consider their expected payoff to be smaller under the no-leakage situation; that is, three-player bargaining. Hence, the result that the management group's decision departs from shareholders' expectation continues to hold.

Finally, as argued in Williamson (2008), there are some observed disparities between boards in theory and in practice. For example, in order to focus on the board's incentive to retain the incumbent $\mathrm{CEO}$ in the absence of the incumbent CEO's influence, I consider that all board members have the same utilities. That is, I postulate that the utility of all directors aligns with that of shareholders, and they are therefore treated as a single player. Doing this allows us to discern minutely the important aspect of the board that I discuss in this paper. However, readers must be aware that board composition or directors with different utilities must not be neglected given the other purposes of the board.

\section{Appendix A}

Appendix A1. Deriving $\pi_{G}>\pi_{I}>\pi_{B}, \pi_{G}>\pi_{N}>\pi_{B}, \pi_{G}>\pi_{O}>\pi_{B}, \pi_{I}>\pi_{N}$, and $\pi_{I}>\pi_{O}$ by the Bayes Rule

The CEO's talent is exogenously given as $a_{i}, i \in\{T, S\}$, where $a_{T}$ defines that the CEO is talented, and $a_{S}$ defines that the CEO is substandard. No player knows the true talent of the CEO, and there is no information asymmetry among the players. The prior distribution of the talent of the incumbent CEO is given exogenously as $\gamma^{i}, i \in\{T, S\}$, where $\gamma^{T}>\gamma^{S}$, and $\gamma^{T}+\gamma^{S}=1$. I assume that both the board and the incumbent CEO hold a subjective probability distribution of the incumbent CEO's talent that he is $T$ with probability $\gamma^{T}>\frac{1}{2}$. On the other hand, the prior distribution of the talent of any new potential CEO, regardless of whether he is an internal or an external candidate, is assumed to be $\frac{1}{2}$ for being $a_{T}$ or $a_{S}$. The profit of the firm under the incumbent CEO or an internally promoted CEO is denoted as $X_{j}, j \in\{H, L\}$, where $X_{H}>X_{L}>0$.

Then the conditional probability of an outcome dependent on the talent of the incumbent or internal CEO is expressed as $P_{j}^{i} \equiv \operatorname{Pr}\left\{X_{j} \mid a_{i}\right\}$. For example, $P_{L}^{T}$ is the probability that the CEO produces $X_{L}$ conditional on $a_{T}$. See Table A. 
Table A

\begin{tabular}{|c|c|c|}
\hline & $a_{T}$ & $a_{S}$ \\
\hline$X_{H}$ & $P_{H}^{T}$ & $P_{H}^{S}$ \\
\hline$X_{L}$ & $P_{L}^{T}$ & $P_{L}^{S}$ \\
\hline
\end{tabular}

I assume $P_{H}^{T}>P_{H}^{S}$, and hence, $P_{L}^{S}>P_{L}^{T}$ holds. Given these assumptions, the expected firm profit conditional on the CEO's talent is expressed as $E(X \mid T) \equiv P_{H}^{T} X_{H}+P_{L}^{T} X_{L}$ when the CEO's true talent is $a_{T}$. It is expressed as $E(X \mid S) \equiv P_{H}^{S} X_{H}+P_{L}^{S} X_{L}$ when the CEO's true talent is $a_{S}$.

Thus, the unconditional expected firm profit is expressed as:

$$
\pi_{N} \equiv \frac{1}{2} E(X \mid T)+\frac{1}{2} E(X \mid S)
$$

when the CEO is appointed internally from the board. It is expressed as:

$$
\pi_{I} \equiv \gamma^{T} E(X \mid T)+\gamma^{S} E(X \mid S)
$$

when the incumbent CEO serves to the end of the game without his talent being updated.

If the incumbent $\mathrm{CEO}$ is monitored, the prior distribution of his talent is updated through the Bayes rule. See Table B.

Table B with probability $p$

\begin{tabular}{|c|c|c|}
\hline & $a_{T}$ & $a_{S}$ \\
\hline$y_{G}$ & $R_{G}^{T}$ & $R_{G}^{S}$ \\
\hline$y_{B}$ & $R_{B}^{T}$ & $R_{B}^{S}$ \\
\hline
\end{tabular}

with probability $(1-p)$

\begin{tabular}{|c|c|c|}
\hline & $a_{T}$ & $a_{S}$ \\
\hline$y_{I}$ & 1 & 1 \\
\hline
\end{tabular}

$y \in\left\{y_{G}, y_{B}, y_{I}\right\}$ is the signal the board obtains regarding the incumbent CEO's talent. Informative information $\left\{y_{G}, y_{B}\right\}$ is obtained with probability $p$ and uninformative information $\left\{y_{I}\right\}$ is obtained with probability $(1-p)$. The probability distribution on $\left\{y_{G}, y_{B}\right\}$ conditional on the talent of the incumbent CEO is expressed as $R_{j}^{i}=\operatorname{Pr}\left\{y_{j} \mid a_{i}\right\}$. When the board obtains informative signal, it receives $y_{G}$ with probability $q$, and $y_{B}$ with probability $(1-q)$. When the board receives $y_{G}$, the subjective probability that the incumbent CEO has a talent $a_{T}$, is updated from $\gamma^{T}$ to $\frac{\gamma^{T} R_{G}^{T}}{\gamma^{T} R_{G}^{T}+\gamma^{S} R_{G}^{S}} \equiv \mu_{G}^{T}$. It is assumed that $\mu_{G}^{T}>\gamma^{T}>\frac{1}{2}$ $\left(\mu_{G}^{S}=1-\mu_{G}^{T}<\frac{1}{2}\right)$ for the monitoring raises the expected outcome of the firm if the incumbent CEO is believed to be likely to be $a_{T}$. Likewise, $\mu_{B}^{T} \equiv \frac{\gamma^{T} R_{B}^{T}}{\gamma^{T} R_{B}^{T}+\gamma^{S} R_{B}^{S}}$, and this is assumed to be $\mu_{B}^{T}<\frac{1}{2}\left(\mu_{B}^{S}>\frac{1}{2}\right)$. When the board receives $y_{I}$, the subjective probability about the CEO's talent being $a_{T}$ remains unchanged at $\gamma$. Given these assumptions, the unconditional 
expected firm profit is expressed as:

$$
\pi_{G} \equiv \mu_{G}^{T} E(X \mid T)+\mu_{G}^{S} E(X \mid S)
$$

when the board receives $y_{G}$. It is expressed as:

$$
\pi_{B} \equiv \mu_{B}^{T} E(X \mid T)+\mu_{B}^{S} E(X \mid S)
$$

when the board receives $y_{B}$.

Lastly, I denote as $\pi_{O}$ the unconditional expected firm profit which is expressed as:

$$
\pi_{O} \equiv \frac{1}{2} E(Z \mid T)+\frac{1}{2} E(Z \mid S) .
$$

The profit of the firm under a new externally recruited CEO is denoted as $Z_{j}, j \in\{H, L\}$, where $Z_{H}>Z_{L}>0$. The conditional probability of an outcome dependent on the talent of the new CEO is defined in a similar way as that of the incumbent and internally promoted CEO. Thus, $E(Z \mid T)$ is the expected firm profit when the externally hired CEO's true talent is $a_{T}$ and $E(Z \mid S)$ is the expected firm profit when his true talent is $a_{S}$.

As a result, the relations $\pi_{G}>\pi_{I}>\pi_{B}, \pi_{G}>\pi_{N}>\pi_{B}, \pi_{G}>\pi_{O}>\pi_{B}, \pi_{I}>\pi_{N}$ are induced by the Bayesian update, and I also assume $\pi_{I}>\pi_{O}$.

q.e.d.

\section{Appendix A2: The Proof of Proposition 2}

I first prove equation (10). If the board determines to recruit externally, the Nash product is represented by (4). I denote $\theta_{B}$ and $\theta_{C}$ as the threat points of each of the players, where $\left(\theta_{B}, \theta_{C}\right)$ is assumed to be an interior point of the feasible set. In this model, whatever the amount of the threat point that is in the interior of the feasible set, it does not affect the decisions regarding the succession policy and the monitoring levels. I denote the first large bracket in (4) as $A$ and the second as $B$. Then, the first-order condition maximizing $V_{O}$ with respect to $p$ yields:

$$
\frac{\partial A}{\partial p} B+\frac{\partial B}{\partial p} A=0
$$

Next, I derive the first-order condition maximizing $V_{O}$ with respect to $w$. The first-order 
condition with respect to $w$ yields:

$$
-B+A=0
$$

Thus, (A1) and (A2) yield $\frac{\partial A}{\partial p}+\frac{\partial B}{\partial p}=0$. Hence, this is the maximization of the joint expected utility, w.r.t. $p$. Organize this, and $d^{\prime}(p)$ is obtained as:

$$
d^{\prime}(p)=q \pi_{G}+(1-q) \pi_{O}-\pi_{I}-(1-q)\left(b+w_{O}\right),
$$

which is the level of monitoring as shown in (10). Thus, the frontier is expressed as a 45-degree line, for $w$ is transferable.

It follows from (A2) that the wage $w$ is determined as:

$$
w=\frac{1}{2}\left\{\begin{array}{c}
p q \pi_{G}+p(1-q)\left(\pi_{O}-w_{O}\right)-(1-p) \pi_{I}-d(p) \\
-\theta_{B}+\theta_{C}-[p q+(1-p)] b .
\end{array}\right\}
$$

Next, I prove (11). If the board determines to promote one of the internal incumbent directors, the Nash product is expressed by (5). I denote $\theta_{B}$ and $\theta_{C}$ as the threat points of each of the players, where $\left(\theta_{B}, \theta_{C}\right)$ is assumed to be an interior point of the feasible set. I denote the first bracket in (5) as $A$ and the second as $B$. Then, the first-order condition maximizing $V_{I}$ with respect to $p$ yields:

$$
\frac{\partial A}{\partial p} B+\frac{\partial B}{\partial p} A=0
$$

Next, I derive the first-order condition maximizing $V_{I}$ with respect to $w$. The first-order condition with respect to $w$ yields:

$$
-B+A=0
$$

Thus, from (A3) and (A4), $\frac{\partial A}{\partial p}+\frac{\partial B}{\partial p}=0$ is obtained. Hence, this is the maximization of the joint expected utility, w.r.t.p. Then, organize this to obtain $d^{\prime}(p)$, which is expressed as:

$$
d^{\prime}(p)=q \pi_{G}-\pi_{I}+(1-q) \pi_{N}-(1-q) \frac{\pi_{N}-w_{N}}{n},
$$

which is the level of monitoring as shown in (11). Thus, the frontier is expressed as a 45-degree line, for $w$ is transferable.

It follows from (A4) that the wage $w$ is determined as: 


$$
w=\frac{1}{2}\left\{\begin{array}{c}
p q \pi_{G}+p(1-q)(n-1)\left(\frac{\pi_{N}-w_{N}}{n}+w_{N}\right)+(1-p) \pi_{I}-d(p) \\
-\theta_{B}+\theta_{C}+b(2 p-2 p q-1) .
\end{array}\right\}
$$

q.e.d.

\section{Appendix A3. The Proof for Social Surplus Maximization in Section 4.1}

The expected utility of the whole group under external recruiting policy

The expected utility for the board is:

$$
p q \pi_{G}+p(1-q)\left(\pi_{O}-w_{O}\right)+(1-p) \pi_{I}-w-d(p) .
$$

The expected utility for the incumbent CEO is:

$$
p q b+(1-p) b+w
$$

The expected utility for the potential CEO is:

$$
p(1-q)\left(b+w_{O}\right)
$$

Thus, from (A5), (A6), and (A7), the sum of all three players' utilities derived as a result of Nash bargaining, is expressed as:

$$
p q \pi_{G}+p(1-q) \pi_{O}+(1-p) \pi_{I}-d(p)
$$

and the equilibrium monitoring level is derived as:

$$
d^{\prime}(p)=q \pi_{G}+(1-q) \pi_{O}-\pi_{I}
$$

The expected utility of the group under the internal promotion policy

The expected utility for the board is:

$$
p q \pi_{G}+p(1-q)\left[\frac{n-1}{n}\left(\pi_{N}-w_{N}\right)+b+w_{N}\right]+(1-p) \pi_{I}-w-d(p),
$$

where the potential new CEO's expected utility is internalized in the above expected utility as $p(1-q)\left(b+w_{N}\right)$. This is because one of the incumbent directors becomes the new CEO if the incumbent $\mathrm{CEO}$ is dismissed. The expected utility of the incumbent CEO is the same as that of the external recruiting policy, and it is (A6). 
The expected utility of the new director hired after the CEO replacement, who will be considered as a newcomer to the group under the internal-promotion policy, is expressed as:

$$
p(1-q) \frac{1}{n}\left(\pi_{N}-w_{N}\right) .
$$

From (A6), (A9), and (A10), the sum of all three players derived as a result of Nash bargaining is expressed as:

$$
p q \pi_{G}+p(1-q) \pi_{N}+(1-p) \pi_{I}-d(p),
$$

and the equilibrium monitoring level is derived as:

$$
d^{\prime}(p)=q \pi_{G}+(1-q) \pi_{N}-\pi_{I} .
$$

From (A8) and (A11), the optimum monitoring level for the group is expressed as:

$$
d^{\prime}(p)=q \pi_{G}+(1-q) \operatorname{Max}\left\{\pi_{O}, \pi_{N}\right\}-\pi_{I},
$$

which is the monitoring level shown in (15).

q.e.d.

\section{Appendix A4: The Proof of Renegotiation about the Succession Policy}

Below I show that even if the existing board redetermines the succession policy after the incumbent CEO's tenure has been terminated, it still adopts the same succession policy as what has been determined together with the incumbent CEO in the first stage.

If the board were to redetermine the succession policy, it would take place between the third and fourth stages. At this stage, the wage to the incumbent CEO and $d(p)$ are already determined, and they cannot change the contract even after the CEO has been dismissed. Therefore, the board's expected utility will be expressed as:

$$
\pi_{O}-w_{O}
$$

if they decide to hire externally. On the other hand, if the board decides to recruit one of the internal candidates as the new CEO, its expected utility will become:

$$
(n-1) \frac{\pi_{N}-w_{N}}{n}+\left(b+w_{N}\right) .
$$


The comparison of (A12) and (A13) yields the same result as Proposition 1.

q.e.d.

Appendix A5: The Proof that the incumbent CEO and the board do not involve a potential new CEO in the negotiation even if they could

For clarity, I use the expression "two-player bargaining" for bargaining between the board and the incumbent CEO, and "three-player bargaining" for bargaining between the board, the incumbent CEO, and the potential CEO. I also assume that the potential CEO has bargaining power. That is, such CEOs are assumed to have some firm/industry-specific knowledge that gives them the bargaining power. Such CEOs are limited in the market.

Below I show that the board and the incumbent CEO can negotiate with a potential CEO, which will cause them no leakage from the bargaining surplus: three-player bargaining. However, under three-player bargaining, the expected payoffs to the board and the incumbent CEO may become smaller than the expected payoffs that they could obtain from two-player bargaining, depending on the parameters. Moreover, the stronger the potential CEO's bargaining power and/or opportunity cost, the greater the potential CEO's share and hence the smaller the board's and the incumbent CEO's expected payoffs. That is, the model in this paper may look like the board and the incumbent CEO are negotiating by themselves because that is the only choice that they have, but below I show that two-party negotiation is the result of omitting the potential CEO. That is, the board and the incumbent CEO first have the choice of whether to undertake three-player bargaining or two-player bargaining, but the present paper has focused on the case in which they do not involve the potential CEO (two-player bargaining), because doing so makes them better off.

Below I consider three-player bargaining. I must note that there is a case in which both the board's and the incumbent CEO's expected payoffs are always larger under three-player bargaining than under two-player bargaining. However, this is confined to the unique case where the threat point of the board and the incumbent CEO under three-player bargaining equals the bargaining solution of the two-player bargaining. I confirm that this scarcely occurs. To do so, I denote the threat point of the board and the incumbent CEO under the two-player bargaining game to be $\theta_{B}$ and $\theta_{C}$, and that under three-player bargaining game to be $\eta_{B}$ and $\eta_{C}$. Next, denote the payoffs to the board, the incumbent CEO, and a potential CEO to be $B, C$, and $N$, respectively. Furthermore, denote the Pareto frontier for the threeplayer bargaining to be $\pi_{1}$, and that for the two-player bargaining to be $\pi_{2}$. Clearly, $\pi_{1}>\pi_{2}$ 
holds. If I assume that $\eta_{B}$ and $\eta_{C}$ equal the bargaining solution of the two-player bargaining game, the following expressions must hold: $B+C+N=\pi_{1}$ and $\eta_{B}+\eta_{C}=\pi_{2}$. The threat point of the potential CEO, $\eta_{N}$, can be anything as long as $\eta_{B}+\eta_{C}+\eta_{N}$ is less than $\pi_{1}$. In this situation, three-player bargaining always yields larger utilities for the board and the incumbent CEO. However, this rarely occurs.

The reason that the above relationships scarcely occur is that the potential CEO must be compensated for his opportunity cost if the negotiation breaks down. In other words, the potential CEO is not just a worker without skills/experience/reputation selected from a competitive market. Instead, he is a person with certain experience and some firm/industryspecific knowledge. Such a person has his own job and may be offered several positions elsewhere. If he decides to enter into negotiation for the CEO's position in a new firm, which requires some effort and time, this firm must compensate him for his opportunity cost. Therefore, the correct scenario would be $B+C+N=\pi_{1}$ and $\eta_{B}+\eta_{C}=\pi_{2}$ - "potential CEO's opportunity cost". Hence, three-player bargaining does not always improve the board and the incumbent CEO's expected payoffs. Therefore, under three-player bargaining, the expected payoffs to the board and the incumbent CEO may become smaller than the expected payoffs that they could obtain from two-player bargaining.

q.e.d.

\section{Appendix A6. A Simple Model of Leakage}

\section{Basic Environment}

In this section, I identify two forms of corporate governance systems: the externalrecruiting system and the internal-promotion system. In both systems, the board consists of one incumbent $\mathrm{CEO}$ and $n$ incumbent directors. Under the external-recruiting system, if the incumbent CEO is fired, a new CEO is always externally hired, and the board members

remain unchanged. Under the internal-promotion system, if the incumbent CEO is fired, one of the incumbent directors is promoted and becomes the new CEO, and to maintain the board size, a new director is hired. Therefore, under an external-recruiting system, the newcomer is the newly hired CEO, and under an internal-promotion system, the newcomer is the newly hired director.

Players: There are two players: the board of directors and the incumbent CEO. There are $n$ incumbent directors on the board, but they are treated as one player. The CEO is 
either talented $T$ or substandard $S$, determined by nature, with no one knowing the CEO's true talent. The distribution of the incumbent CEO's talent is the same as that of any other potential CEO, and it is $1 / 2$ for being $T(S)$. Given that the incumbent CEO here is no different from the potential CEO, he does not have bargaining power to negotiate his own wage with the board of directors.

Information Gathering Strategy: When the board hires the specialist to monitor the CEO, the specialist provides the board with precise information about the CEO's true talent with probability one. Then, with probability $q$, the CEO is discovered to be of type $T$, and with probability $(1-q)$, type $S$. When the board does not hire the specialist, the board's prior belief about the incumbent CEO's true talent remains unchanged. The incumbent CEO is replaced with a new CEO when he is discovered to be of type $S$, but otherwise he is retained. The payment to the specialist, that is, monitoring cost, is a constant $c$.

Payoffs: The board objective is to maximize its utility: the profit of the firm, less the monitoring cost and the wage of the CEO, where the profit of the firm is dependent on the talent of the CEO. For the sake of simplicity, the board profit equals the corporate profit. The expected profit of the firm is denoted as $\pi_{N}$ when the incumbent CEO is retained without monitoring. This is also the same when the incumbent $\mathrm{CEO}$ is fired and a new CEO is hired. The expected corporate profit when the incumbent CEO is of type $T$ is denoted $\pi_{G}$, and it is denoted as $\pi_{L}$ when he is of type $S$. In short, $\pi_{G}>\pi_{N}>\pi_{L}$ is assumed. The CEO's objective is to receive both the wage and the private benefit, such as reputation or status. The CEO will receive the wage regardless of his situation, but the private benefit is only given to the CEO who is serving at the last stage of the game. The reservation utility of the CEO is assumed to be $r$.

Timing: In the first stage, the board posts an offer that the incumbent CEO must either accept or reject. The board offers $(p, w)$, where $p \in\{0,1\}: 0$ meaning no monitoring by the specialist and 1 meaning there will be monitoring by the specialist. The specialist is hired by the board of directors at a fixed cost of $c . w$ is the wage offered to the CEO. To be more precise, the board offers the incumbent CEO $(p, w)=\left(1, w_{1}\right)$ or $(p, w)=\left(0, w_{0}\right)$. In the case of $p=1$, with probability $q$, the specialist gives the board precise information that the CEO is of type $T$. With probability $(1-q)$, the board receives precise information about the CEO's talent to be of type $S$. In the second stage, the CEO accepts or rejects the offer. The profit of the firm is realized, and players receive their profits.

\section{A Simple Model}


The players' expected utilities when the board offers $(p, w)=\left(0, w_{0}\right)$ In this case, there is no monitoring, and hence, the incumbent CEO serves to the end of the game without his talent being updated in either the external-recruiting system or the internal-promotion system. In other words, all the incumbent players are retained to the end of the second stage, and there will be no newcomer. Thus, the expected utilities of the players are the same in both systems; the board's expected utility is expressed as:

$$
\pi_{N}-w_{0}
$$

and the incumbent CEO's expected utility is expressed as:

$$
b+w_{0}
$$

The players' expected utilities when the board offers $(p, w)=\left(1, w_{1}\right)$ In this case, the board's utilities are different for the two systems. This is because under an externalrecruiting system, discovering that the incumbent CEO is substandard $(S)$ is equivalent to saying that the incumbent $\mathrm{CEO}$ is fired and a new CEO is externally hired, whereas under an internal-promotion system, it is equivalent to saying that the incumbent CEO is fired and a new CEO is internally promoted. Therefore, the board's expected utility in the external-recruiting system is expressed as:

$$
q \pi_{G}+(1-q) \pi_{N}-w_{1}^{O}-c
$$

and the incumbent CEO's expected utility is expressed as:

$$
q b+w_{1}^{O}
$$

The first and second terms of (A16) represent the expected profit to the board. That is, the board finds the CEO talented $(T)$ with probability $q$, and finds him substandard $(S)$ with probability $(1-q)$, and fires him and hires a new CEO. The third term is the wage that the board pays to the incumbent CEO, which is offered to him at the first stage. The last term is the cost of monitoring. ${ }^{36}$ As for (A17), the CEO receives $w_{1}^{O}$ regardless of whether or not he serves to the last stage of the game but receives the private benefit $b$ only when he

\footnotetext{
${ }^{36}$ If $b>\frac{\pi_{N}}{n}$ holds, the directors under both systems may conduct monitoring when the cost of monitoring is small enough to satisfy $q\left(\pi_{G}-\pi_{N}\right)-(1-q) b>c$. However, if the cost is $q\left(\pi_{G}-\pi_{N}\right)-(1-q) \frac{\pi_{N}}{n}>$ $c>q\left(\pi_{G}-\pi_{N}\right)-(1-q) b$, then only the directors under the internal-promotion system monitor. If $c>$ $q\left(\pi_{G}-\pi_{N}\right)-(1-q) \frac{\pi_{N}}{n}$, then the cost of monitoring is too large, meaning that the directors do not monitor in either system. A similar argument holds for the case in which $\frac{\pi_{N}}{n}>b$ holds.
} 
is retained.

On the other hand, the board's expected utility under an internal-promotion system is expressed as:

$$
q \pi_{G}+(1-q)\left[b+(n-1) \frac{\pi_{N}}{n}\right]-w_{1}^{I}-c
$$

and the incumbent CEO's expected utility is expressed as:

$$
q b+w_{1}^{I}
$$

The CEO's expected utility (A19), is as (A17). The difference between an external-recruiting system and an internal-promotion system appears in the second term of the board's utilities. With probability $(1-q)$, the board finds the incumbent CEO substandard $S$, and hence, it replaces the incumbent $\mathrm{CEO}$ with a new $\mathrm{CEO}$, who was originally one of the board members. Recall that a new director is hired in this case to keep the board size at $n$. Thus, with probability $(1-q)$, one of the original board members obtains $b$, and each of the remaining $(n-1)$ directors receives $\frac{\pi_{N}}{n}$.

The board's optimal choice Given these expected utilities, the board makes the optimal choice in the first stage in offering $\left(0, w_{0}\right)$ or $\left(1, w_{1}\right)$, provided that the CEO will accept the offer in the second stage.

External-recruiting system If the board posts $\left(0, w_{0}\right)$, the wage is determined to satisfy $b+w_{0}=r$, but if it posts $\left(1, w_{1}^{O}\right)$, the wage is determined to satisfy $q b+w_{1}^{O}=r .{ }^{37}$ Thus, the board's optimal choice is made between $\left(0, w_{0}\right)=(0, r-b)$ and $\left(1, w_{1}^{O}\right)=(1, r-q b)$. Substituting $w_{0}=r-b$ into (A14) yields:

$$
\pi_{N}+b-r
$$

Substituting $w_{1}^{O}=r-q b$ into (A16) yields:

$$
q \pi_{G}+(1-q) \pi_{N}+q b-r-c .
$$

Therefore, the board decides whether to hire the specialist to monitor the CEO by comparing (A20) and (A21). When $b$ is sufficiently small, (A21) $<(\mathrm{A} 20)$ holds, and as a result, the board posts $\left(1, w_{1}^{O}\right)$. When $b$ is large, $(\mathrm{A} 20)>(\mathrm{A} 21)$ holds, and as a result, the board posts $\left(0, w_{0}\right)$. Recall that $b$ is the private benefit that is given only to the CEO serving at the last

\footnotetext{
${ }^{37}$ It is assumed that $b>r$. When the board offers $\left(0, w_{0}\right)$, the wage $w_{0}$ is determined as to satisfy $w_{0}+b=r$. Because the CEO serves to the end of the game when $\left(0, w_{0}\right)$ is offered, the CEO knows that he will eventually receive $b>0$. This is the same as for an internal-promotion system.
} 
stage and will be regarded as leakage by the incumbent board if the incumbent CEO does not receive it. Thus, if the leakage of $b$ is large, the board posts $\left(0, w_{0}\right)$ in order not to replace the incumbent CEO.

Internal-promotion system The wage level is determined to satisfy $b+w_{0}=r$ when the board posts $\left(0, w_{0}\right)$, while it is determined to satisfy $q b+w_{1}^{I}=r$ when it posts $\left(1, w_{1}^{I}\right)$. Thus, the board makes the optimal choice between $\left(0, w_{0}\right)=(0, r-b)$ and $\left(1, w_{1}^{I}\right)=(1, r-q b)$. Substituting $w_{0}=r-b$ into (A14) yields:

$$
\pi_{N}+b-r
$$

Substituting $w_{1}^{I}=r-q b$ into (A18) yields:

$$
q \pi_{G}+(1-q)\left[b+(n-1) \frac{\pi_{N}}{n}\right]+q b-c-r .
$$

The board's decision whether or not to post an offer to monitor is determined by comparing (A22) and (A23). When $\frac{\pi_{N}}{n}$ is sufficiently small, (A22) $<(\mathrm{A} 23)$ holds, and as a result, the board posts $\left(1, w_{1}^{I}\right)$. When $\frac{\pi_{N}}{n}$ is sufficiently large, (A22) $>(\mathrm{A} 23)$ holds, and as a result, the board posts $\left(0, w_{0}\right)$. In this system, the pay to the new director $\frac{\pi_{N}}{n}$, is the leakage, and again, if the amount of leakage is large, the board chooses not to monitor in order to avoid the leakage.

Definition Leakage is defined as the expected profit that is lost from the incumbents' joint expected utility. This leakage occurs to the incumbents' profits when the incumbent CEO is replaced, the replacement of which leads to a member change within the incumbent members.

This Appendix is used to show that the monitoring that is intended to fire the incumbent CEO induces a leakage to the incumbent members' joint expected utility, and because of this, whether to hire the specialist to monitor the CEO is not solely determined by a trade-off between the positive effect of increase in the expected profit, which is shown by $\pi_{G}-\pi_{N}$, and the negative effect of monitoring cost $c$. That is, if the marginal profit gained by monitoring the CEO exceeds the addition of the monitoring cost and the amount of leakage from the expected joint utility of the incumbents, the board has an incentive to hire the new CEO, and thus, it posts an offer of 'monitor.' In other words, if the amount of leakage is large, the board does not monitor for the sake of reducing the risk of having leakage. Note that the board has to consider which type of leakage ( $b$ or $\frac{\pi_{N}}{n}$ ) it will incur if it is given the option of choosing where to bring the next CEO from. 


\section{Appendix B}

\section{Anecdotal Evidence}

In practice, when the board replaces the CEO if the firm shows bad performance, the board must find a new CEO. In this process, most board members keep their seats after the CEO is replaced even though they should also be held responsible for the damage to firm value.

For example, when Carleton Fiorina was forced by the board to resign as CEO and chairman of Hewlett-Packard on the 8 February 2005 due to mismanagement and a lack of leadership, the board had 10 other directors. One of the directors, Sanford Litvack, retired on 2 February, a month before his planned retirement. His position was soon replaced by Thomas Perkins, who used be on the board. Another director, Robert Knowling Jr also retired on 23 September 2005, but he stated his retirement was due to becoming a chief executive of another company. His position was also soon replaced by John Hammergren. In short, when Carleton Fiorina was forced out, none of the directors left with her. Another interesting fact about HP is that they tend to keep board size stable by filling vacancies in the board caused by the departure of existing members.

The case of Groupon provides another example of CEO replacement without a change in the board composition. The CEO and the co-founder, Andrew Mason, was removed from the CEO position on 28 February 2013. At the time of his departure, Groupon had seven other directors. None of the directors was fired with him. As of 1 August 2013, all seven of them are still serving on the board, with one of them being a successor CEO. In short, the board of directors removed Andrew Mason, promoted the then chairman of the board as a new $\mathrm{CEO}$, and have not refilled the vacancy in the board for five months.

Lastly, another example of CEO replacement without a change in the composition of board members is the case of Yahoo! following Microsoft's failed takeover. The CEO was forced to leave the firm after the proxy fight in Yahoo!. While this is not exactly the same as the topic addressed in this paper, where the CEO is fired by the board, they are the same in the sense that the CEO hugely damages the firm, but only the CEO is laid off, and the remaining board members are retained. Below is a relevant quote from Kim et al. (2010, pp. 117-118).

"Throughout 2007, Yahoo! was losing ground to Google in their competition for internet search advertising. To try and revive a stagnant stock price, Yahoo! replaced its CEO in June 2007 with company founder Jerry Young. However, changes in strategy under the new CEO 
did not improve Yahoo!'s success and Microsoft initiated discussions of a proposed acquisition of Yahoo!. . . The Yahoo! board, led by Jerry Young, rejected Microsoft's proposal. In January 2008, Yahoo's performance had fallen even further and the company was forced to lay off 1000 employees. Its stock price fell below 20 dollars per share, which was the lowest price in years. In February 2008, Microsoft decided to again try to takeover Yahoo!, but it went around the board and offered 31 dollars per share directly to the shareholders. This represented a 62 percent premium above the previous day closing price of 19.18 dollars per share. ... The Yahoo! board, however, rejected the Microsoft offer, claiming it substantially undervalued Yahoo! In follow up negotiations, Microsoft raised its offer to 33 dollars, but the Yahoo! board's minimum price was 37 dollars. . . This effectively raised the cost of a takeover beyond the price per share offered. The combination of the board resisting the proposed takeover and the poison pill caused Microsoft to walk away from the deal. ... On the day Microsoft announced it was walking away, the stock price fell to 23 dollars and then in the next few months fell below 20 dollars. . . Following a high-profile proxy fight led by Carl Icahn to oust all the directors on the board because they rejected the Microsoft bid, Yahoo! was forced to make changes. The company added additional outside board members and eventually replaced its CEO in January 2009." Note that Carl Icahn's proposal was to replace all the existing nine directors who had rejected Microsoft's offer. However, after a contentious fight for the votes of shareholders, Icahn had to accept the compromise solution: Icahn and two of his nominated directors became part of an expanded Yahoo! board, leaving in place eight of the nine directors who had rejected Microsoft. In short, only one director lost his position.

\section{References}

Adachi-Sato, M. (2013). 'Incentive Pay that Causes Inefficient Managerial Replacement', CIRJE discussion paper F-890, Tokyo University.

http://www.cirje.e.u-tokyo.ac.jp/research/dp/2013/2013cf890.pdf.

Adams, R. B. and Ferreira, D. (2007). 'A Theory of Friendly Boards', Journal of Finance, Vol. 62, pp. 217-250.

Aghion, P. and Bolton, P. (1987). 'Contracts as a Barrier to Entry', American Economic Review, Vol. 77, pp. 388-401.

Agrawal, A., Knoeber, C. R. and Tsoulouhas, T. (2006). 'Are Outsiders Handicapped in CEO Successions?', Journal of Corporate Finance, Vol. 12, pp. 619-644. 
Almazan, A. and Suarez, J. (2003). 'Entrenchment and Severance Pay in Optimal Governance Structures', Journal of Finance, Vol. 58, pp. 519-547.

Berry, T. K., Bizjak, J. M., Lemmon, M. L. and Naveen, L. (2006). 'Organizational complexity and CEO labor markets: Evidence from diversified firms', Journal of Corporate Finance, Vol. 12, pp. 797-817.

Bower, J. L. (2007). The CEO Within: Why Inside Outsiders are the Key to Succession Planning, Boston, Harvard Business School Publishing Corporation.

Byrd, J. and Hickman, K. (1992). 'Do Outside Directors Monitor Managers? Evidence from Tender Offer Bids', Journal of Financial Economics, Vol. 32, pp. 195-221.

Clutterbuck, D. (1998). 'Handing over the Reins: Should the CEO's Successor be an Insider or an Outsider?', Corporate Governance, Vol. 6, pp. 78-85.

Coase, R. (1960). 'The Problem of Social Cost', Journal of Law and Economics, Vol. 1, pp. $1-44$.

Harris, M. and Raviv, A. (2008). 'A Theory of Board Control and Size', Review of Financial Studies, Vol. 21, pp. 1797-1832.

Harris, M. and Raviv, A. (2010). 'Control of Corporate Decisions: Shareholders vs. Management', Review of Financial Studies, Vol. 23, pp. 4115-4147.

Hermalin, B. E. and Weisbach, M. S. (1991). 'The Effects of Board Composition and Direct Incentives on Firm Performance', Financial Management, Vol. 20, pp. 101-112.

Hermalin, B. E. and Weisbach, M. S. (1998). 'Endogenously Chosen Boards of Directors and Their Monitoring of the CEO', American Economic Review, Vol. 88, pp. 96-118.

Hermalin, B. E. (2005). 'Trends in Corporate Governance', Journal of Finance, Vol. 60, pp. $2351-2384$.

Inderst, R. and Mueller, H. M. (2010). 'CEO Replacement under Private Information', Review of Financial Studies, Vol. 23, pp. 2935-2969.

Laux, V. (2012). 'Stock Option Vesting Conditions, CEO Turnover, and Myopic Investment', Journal of Financial Economics, Vol. 106, pp. 513-526.

Kim, K. A., Nofsinger J. R., and Mohr, D. J. (2010). Corporate Governance, New Jersey, Prentice Hall.

Ocasio, W. (1999). 'Institutionalized Action and Corporate Governance: The Reliance on 
Rules of CEO Succession', Administrative Science Quarterly, Vol. 44, pp. 384-416.

Parrino, R. (1997). 'CEO Turnover and Outside Succession: A Cross-Sectional Analysis', Journal of Financial Economics, Vol. 46, pp. 165-197.

Raheja, C. G. (2005). 'Determinants of Board Size and Composition: A Theory of Corporate Boards', Journal of Financial and Quantitative Analysis, Vol. 40, pp. 283-306.

Rosenstein, S. and Wyatt, J. G. (1990). 'Outside Directors, Board Independence and Shareholder Wealth', Journal of Financial Economics, Vol. 26, pp. 175-191.

Shleifer, A. and Vishny, R. W. (1989). 'Management Entrenchment: The Case of ManagerSpecific Investments', Journal of Financial Economics, Vol. 25, pp. 123-139.

Warther, V. A. (1998). 'Board Effectiveness and Board Dissent: A Model of the Board's Relationship to Management and Shareholders', Journal of Corporate Finance, Vol. 4, pp. 53-70.

Williamson, O. E. (2008). 'Corporate Boards of Directors: In Principle and in Practice', The Journal of Law, Economics, $\mathcal{G}$ Organizations, Vol. 24, pp. 247-271.

Wilson, R. (1968). 'The Theory of Syndicates', Econometrica, Vol. 36, pp. 119-132. 
Figure 1 : Bargaining frontier under different succession policies

Panel A : Internal promotion succession policy

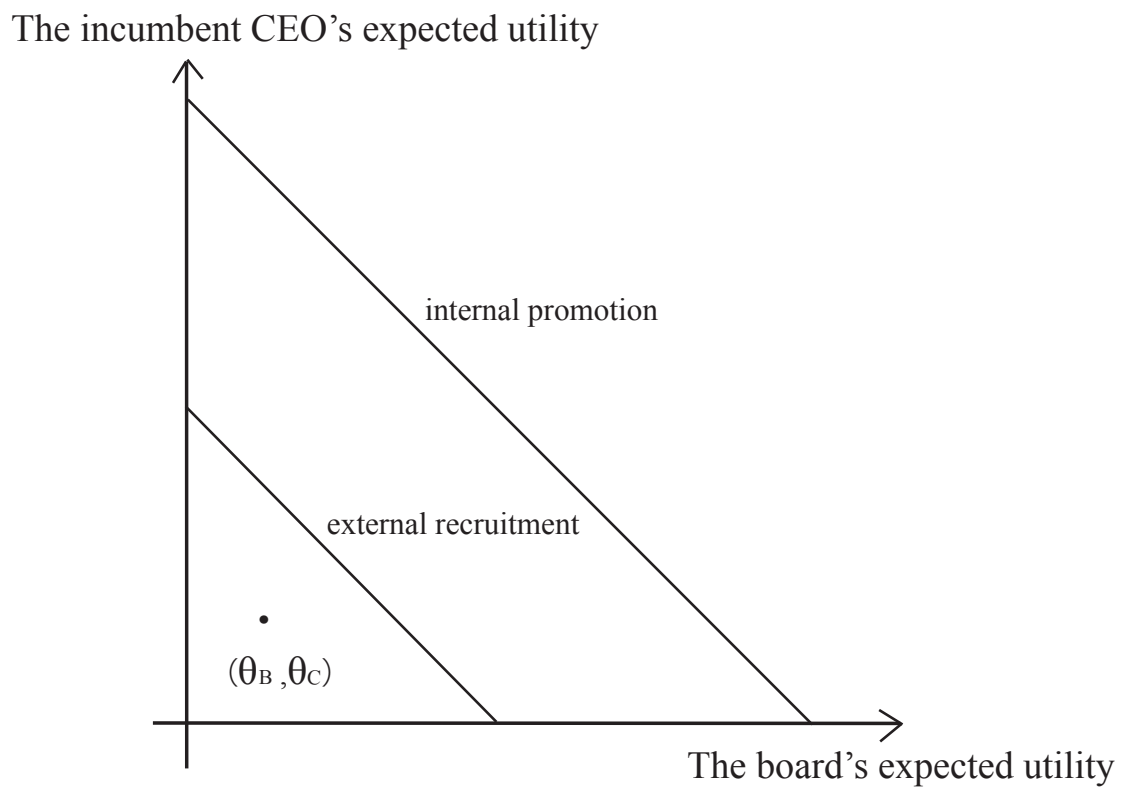

Panel B : External recruitment succession policy

The incumbent CEO's expected utility

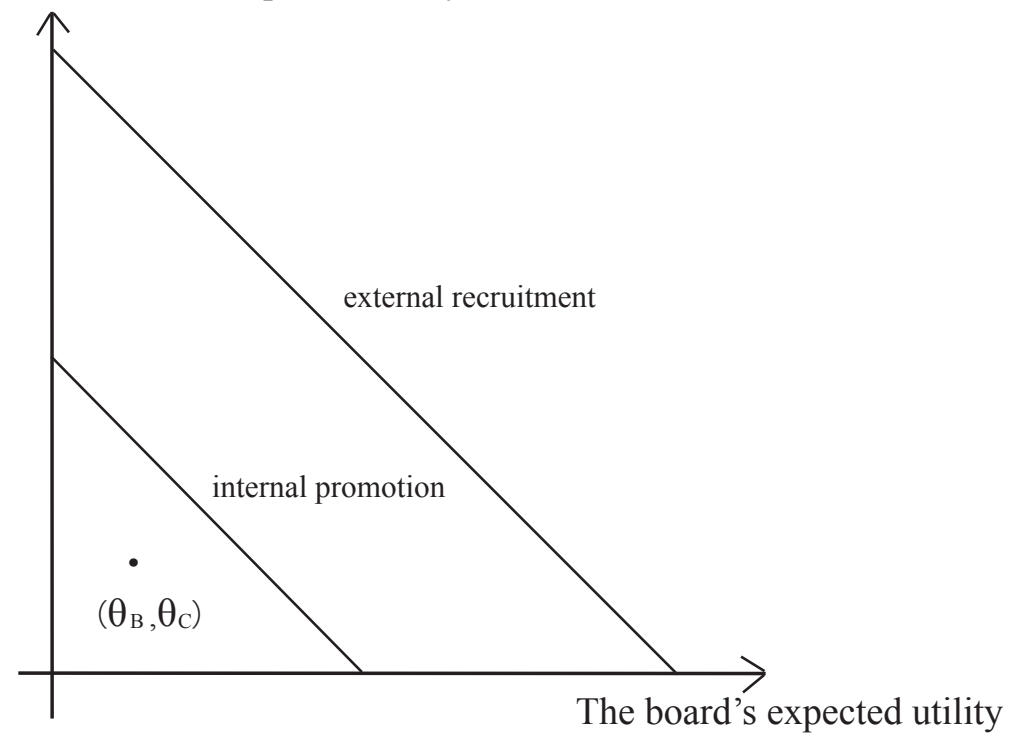

Note : Threat point, $\left(\theta_{\mathrm{B}}, \theta_{\mathrm{C}}\right)$, is the outcome that will occur if there is a breakdown of cooperation; that is, the board will receive $\theta_{\mathrm{B}}$ and the incumbent $\mathrm{CEO}$ will receive $\theta_{\mathrm{c}}$. When the bargaining frontier for internal promotion is far out than that of external recruitment, internal promotion succession policy is chosen, as illustrated in Panel A. When the bargaining frontier for external recruitment is far out than that of internal promotion, external recruitment succession policy is chosen, as illustrated in Panel B. 